\title{
Ekspansja anglicyzmów w języku reklamy prasowej
}

Słow a klucze: zapożyczenia, anglicyzmy, reklama, prasa

Celem niniejszego artykułu jest przedstawienie współczesnych tendencji i kierunków w zakresie ekspansji anglicyzmów w reklamie prasowej. Za anglicyzmy uznaję zarówno leksemy pochodzenia angielskiego, w tym również derywaty od podstaw angielskich utworzone w języku polskim, jak i wszelkie frazy, np. slogany.

Materiał egzemplifikacyjny obejmuje okres pierwszego półrocza 2009 roku i pochodzi z trzech czasopism reprezentujących trzy typy prasy, a zarazem trzy typy odbiorców zróżnicowanych pod względem wieku, płci, wykształcenia i wiedzy specjalistycznej. Dodatkowym kryterium doboru źródeł była analogiczna liczba reklam w poszczególnych czasopismach, co pozwoliło na rzetelne dokonanie porównań ${ }^{1}$.

Tygodnik opinii „Wprost” należy do prasy ogólnej, skierowany jest do najszerszego kręgu odbiorców, w różnym wieku, o zróżnicowanym poziomie wykształcenia, zamożności i wiedzy o świecie. W języku samego czasopisma dominuje polszczyzna ogólna. „PC World” to miesięcznik poświęcony komputerom, skierowany do odbiorcy wyspecjalizowanego w przedmioto-

${ }^{1}$ Liczbie reklam w jednym numerze miesięcznika odpowiada liczba reklam w czterech numerach tygodnika. 
wej dziedzinie. Język, jakim operuje się w czasopiśmie, jest specjalistyczny, ale nie żargonowy, zrozumiały dla osób dobrze zorientowanych w tematyce, lecz niekoniecznie będących zawodowymi informatykami. Czasopismo „Dziewczyna”, także miesięcznik, reprezentuje prasę młodzieżową adresowaną do dziewcząt. W zawartych w nim tekstach przeważa język potoczny z elementami młodzieżowego slangu. Taki dobór źródeł pozwala na wskazanie ścisłej zależności pomiędzy formą, ilością i strategiami wprowadzania anglicyzmów a odbiorca, do którego adresowany jest tekst.

Badania obejmują analizę formalną i ilościową wpływów angielskich, wyodrębnienie poszczególnych zabiegów strategicznych służących ich wprowadzaniu oraz określenie funkcji zapożyczeń angielskich w obrębie tekstu reklamowego. Na potrzeby artykułu wykorzystano klasyfikację zapożyczeń Andrzeja Markowskiego (2000), opartą na trzech kryteriach: przedmiotu zapożyczenia, stopnia przyswojenia oraz pochodzenia. Typy sloganów zostały wyodrębnione na podstawie dokonanego przez Marka Kochana (2003) podziału na slogan właściwy, slogo oraz headline. Część zasadnicza poświęcona jest analizie materiału w poszczególnych czasopismach, podsumowanie stanowi jednocześnie próbę analizy porównawczej.

W tekstach reklamowych zamieszczanych w tygodniku ,Wprost” dominują zapożyczenia właściwe - w zgromadzonym materiale było ich 26. Pod względem stopnia przyswojenia są to zapożyczenia całkowite bądź cytaty. Te ostatnie to głównie nazwy technologii, zwłaszcza samochodowych, a także cechy tychże technologii lub produktów np.: flex-ride 'elastyczna jazda', efficient dynamics 'wydajna dynamika', hybrid drive 'napęd hybrydowy'.

Interesujące są mechanizmy wprowadzania angielskich cytatów. Wpisują się one doskonale w typy strategii tekstowych służących wprowadzaniu zapożyczeń, wyróżnionych przez Agnieszkę Anisimowicz (2001: 13-21):

1. Strategie eksplicytne: bezpośrednie tłumaczenie, np. hybrid drive 'napęd hybrydowy'; wyjaśnienie w tekście po przecinku, myślniku, kropce lub w nawiasie, np. Attention assist - system analizujacy zachowanie kierowcy $i$ doradzajacy przerwę w podróży po zarejestrowaniu pierwszych oznak zmęczenia; System Flex ride. Zawieszenie dostosowujace się do stylu jazdy.

2. Strategie implicytne nastawione na procesy rozumowania w kontekście, przyjmujące trojaką postać: 
a) tekstową, np. Efficient dynamics (mniejsza emisja, większa radość $z j a z d y)$,

b) graficzną, np. napisy cost, heat, cold, noise, nadrukowane na zdjęcia monet, zaparowanej i oszronionej szyby oraz głośnika,

c) mieszaną, graficzno-tekstową, wykorzystaną w dwóch reklamach Toyoty. W pierwszym tekście angielska nazwa technologii Toyota optimal drive 'optymalny napęd' została umieszczona w sąsiedztwie dużego napisu moc oraz drukowanego mała czcionka spalanie. W drugiej reklamie tej samej nazwie towarzyszy podpis Większa moc. Mniejsze spalanie.

Wśród zapożyczeń całkowitych przeważają leksemy niemające polskich ekwiwalentów. Większość z nich dobrze już zakorzeniła się w systemie języka polskiego - notowane są przez słowniki². Takie zapożyczenia, jak menedżer, business, lifting, design czy leasing wprowadza się do polskiego tekstu bez tłumaczenia czy wyjaśniania. Wykazują one dwa typy adaptacji morfologicznych: fleksyjną, np. designu, oraz słowotwórczą, np. przymiotniki dealerski i menedżerski. Nowością jest słowo widget angielskie pot. 'wihajster, patent', oznaczające typ aplikacji na telefony komórkowe. W reklamie telefonów występuje w liczbie mnogiej z polską końcówką -widgety.

Zapożyczenia strukturalne są nieliczne, przy czym często polskie leksemy są tworzone na wzór angielskich konstrukcji składniowych, np. paroizolacja ‘izolacja od pary’ w języku angielskim ma postać wyrażenia złożonego $\mathrm{z}$ dwóch jednostek leksykalnych steam isolation ${ }^{3}$.

Równie rzadko występują zapożyczenia semantyczne, np. filozofia desig$n u$ - rozszerzenie łączliwości frazeologicznej leksemu filozofia pod wpływem angielskiego philosophy; rodzina produktów - kalka z angielskiego products family, użycie polskiego leksemu rodzina w odniesieniu nie tylko do osób, ale do przedmiotów ${ }^{4}$; dedykowany do montażu - od angielskiego dedicated w znaczeniu 'wydzielony, przeznaczony do specjalnych celów, pasujący tylko do jednego modelu'.

Pośród dłuższych cytatów angielskich zdecydowanie dominują slogany (25) z przewagą sloganów właściwych. Pod względem syntaktycznym naj-

2 Por. np. B. Dunaj (red.) 2001; E. Polański (red.) 2007.

${ }^{3}$ Problem klasyfikacji tego typu kalk szerzej omawia Agnieszka Otwinowska-Kasztelanic (1998: 57-65).

${ }^{4}$ Por. W. Chłopicki, J. Świątek 2001: 322. 
częściej przyjmują formę równoważników zdań, por. Honda - the power of dreams 'siła marzeń', fusing tradition and innovation 'łącząc tradycję $\mathrm{z}$ innowacją’; to see, to hear to admire 'widzieć, słyszeć, podziwiać'; zdań w trybie oznajmującym, por. Lipton, Tea can do that 'herbata może to zrobić', Together we can do more 'razem możemy wiecej' lub rzadziej rozkazującym, por. Ford. feel the difference 'poczuj różnicę', Hyundai drive your way 'jedź swoją drogą / na swój sposób'.

Wyjątek stanowi reklama zegarków Panerai, w której angielski jest zarówno slogan Inspired by the past, build for the future 'inspirowany przeszłością, stworzony dla przyszłości', jak również opis produktu: Hand-wound mechanical movement, water resistance 300 metres, steel case 'mechanizm nakręcany ruchem ręki, wodoodporność do $300 \mathrm{~m}$, stalowa obudowa'.

Do najczęściej stosowanych zabiegów retorycznych należą gry słów, głównie z nazwą produktu, również angielską lub angielsko brzmiącą, wkomponowaną w slogan: Isover - dillema is over 'koniec z dylematami', anywhere in your element - Element to jednocześnie nazwa reklamowanych perfum, jak i angielskie określenie cząsteczki - dosł. 'w każdej cząsteczce twojego ciała'. Not a lot of money - w reklamie Wizzair, w której angielskie słowo LOT 'dużo' zapisane wielkimi literami jest jednocześnie nazwą polskich linii lotniczych. W ten sposób tworzone jest skojarzenie 'LOT - dużo pieniędzy' i tym samym powstaje jasny przekaz - usługi LOT-u są drogie - taniej jest latać z Wizzair. Slogan Suzuki. Way of life - wykorzystuje wieloznaczność angielskiego słowa way 'sposób' życia, ale też 'droga' życia. W wielu analizowanych sloganach ważny jest aspekt brzmieniowy - występują aliteracje bądź paronomazje, por. discover the undiscovered (today, tommorow, toyota), a nawet zabawy słowem czy neologizmy, por. Kup ecoauto z ecodoptata. Zostań ecoista.

Angielskie leksemy i wyrażenia mogą też być wkomponowane w grafikę, np. w reklamach Audi angielskie nazwy zastosowanych w samochodzie rozwiązań technicznych tworzą obraz koła i drogowskazu. Rozumienie ich nie jest warunkiem koniecznym odbioru całego komunikatu, mają się kojarzyć z wysoko zaawansowaną technologią, dodawać prestiżu.

Podsumowując, anglicyzmy w tygodniku „Wprost” pojawiają się najczęściej w reklamach produktów kojarzących się z luksusem: samochodów, perfum, ośrodków odnowy biologicznej, drogich hoteli. Można wysnuć wniosek, iż reklamy takie mają na celu wykorzystanie wciąż obecnego w świadomo- 
ści polskiego odbiorcy stereotypu, że to, co zachodnie, jest lepsze. Może też służyć podkreśleniu, że polski konsument należy już do tego wspólnego europejskiego świata luksusu i ma tak samo łatwy dostęp do oferowanych przezeń dóbr materialnych. Częste gry słów świadczą o tym, że bierze się pod uwagę kompetencję językową odbiorcy, ale jednocześnie, stosując różnego rodzaju podpowiedzi, umożliwia się odbiór także czytelnikom nieposługującym się angielszczyzną.

W miesięczniku „PC World” najwięcej jest zapożyczeń właściwych około 40. W grupie tej dominują zapożyczenia całkowite (27), sporo jest także cytatów (10) oraz 3 częściowo przyswojone. Cytaty to najczęściej nazwy technologii bądź typu usługi, wiele z nich ma formę wyrażeń lub krótkich zdań w formie imperatywu, np. push'n'connect 'naciśnij i połącz', plug and play 'podłącz i graj (używaj)', all-in-one 'wszystko w jednym' określenie systemu zintegrowanego, door-to-door 'od drzwi do drzwi' - typ gwarancji polegającej na tym, że sprzęt wysyłany jest do naprawy i dostarczany do klienta pocztą kurierską na koszt serwisu. Wiele z tych zapożyczeń daje się bezpośrednio przetłumaczyć na polski, jednak przyjęły się w oryginalnej postaci, niektóre zyskały już status terminów komputerowych.

Nieodmienny leksem online przyjmuje dwie formy graficzne: łączną i z łącznikiem on-line - jego pisownia jest do tego stopnia nieustabilizowana, iż jest różnie zapisywany w obrębie jednego tekstu reklamowego. Również wideo występuje zarówno w spolszczonej, jak i w oryginalnej formie.

Najliczniejszą grupę stanowią zapożyczenia całkowite. Sa to nazwy przedmiotów, technologii, usług i czynności niemających swojego odpowiednika w języku polskim. Posiadają polskie końcówki fleksyjne, ale ich zapis graficzny charakteryzuje się bardzo zróżnicowanym stopniem spolszczenia. Przykładowo interfejs, serfuj, biznes, skaler, serwer, wizualizer mają zapis ortograficzny dostosowany do systemu polskiego, lider (leader), piksel ( $p i$ $x e l)$ występują w obu formach graficznych, a chipset 'zespół układów scalonych', overlocker 'osoba modyfikująca komputery, tak aby szybciej działały', design, netbook, router, upscaling 'poprawianie rozdzielczości', leasing, zapisywane są w formie angielskiej.

Zapożyczenia te wykazują produktywność słowotwórczą, np. przymiotnik hostingowy czy rzeczownik odczasownikowy fragowanie od angielskiego frag 'tymczasowo wyeliminować przeciwnika w grze komputerowej'. Szybko adaptują się do systemu fleksji polskiej, por. TV z upscalingiem, pre- 
numerata z netbookiem, komputer z chipsetem, routery, skalery. Leksemy pozornie nieodmienne, np. firmware 'oprogramowanie zaszyte w sprzęcie' zapisywane są z apostrofem firmware’u. Charakterystyczny jest brak strategii tekstowych służących wprowadzaniu zapożyczeń. Z reguły nie są one thumaczone ani objaśniane, zakłada się ich znajomość przez odbiorcę.

Kalki, podobnie jak we „Wprost”, są nieliczne, por.: słowotwórcza Faksmodem 'modem faksowy', zbudowana na wzór angielskich konstrukcji z rzeczownikiem w funkcji przydawki, semantyczne, takie jak strumienie wideo $\mathrm{z}$ angielskiego video stream, Impuls dla rozwoju - dosłowne tłumaczenie angielskiego przyimka for. Po polsku powiemy ,impuls do rozwoju”. Za kalkę można też uznać polski slogan Microsoftu Twój potencjał, nasza pasja, który jest dokładnym odwzorowaniem wersji angielskiej Your potential, our passion. Warto podkreślić, że schemat ten jest produktywny, opiera się na nim kilka innych polskich sloganów, np. Twój talent, nasza technologia. Jedynym odnotowanym typowym zapożyczeniem semantycznym jest opisany już leksem dedykowany - w znaczeniu 'pasujący do określonego modelu'.

Bardziej rozbudowane formy angielskie występują głównie w formie sloganów. Jest ich 29, przy czym zdecydowana większość (22) przybiera formę slogo. Mocne związanie graficzne z logotypem bądź nazwą firmy czy produktu wymusza niejako określoną formę składniową, przeważają zatem krótkie i zwięzłe równoważniki zdań, np. Panasonic - Ideas for life 'pomysły na życie/dla życia', oraz zdania pojedyncze Epson - Exceed your vision 'poszerz swoją wizję'.

Zdarzają się opisy produktów po angielsku, np. digital photo frame 'cyfrowa ramka na zdjęcia', a także napisy wkomponowane w grafikę, np. w reklamie Logitech - naszkicowane na stole kreślarskim słowa: workplace, mobility, ease of use, productivity, compability, Communications, odnoszą się do cech oferowanych produktów, tworzą zestaw pojęć z nimi związanych. W zebranym materiale wystąpiła tylko jedna gra słów: freewolne domeny, w której wykorzystano podobieństwo brzmieniowe słowa frywolny z angielskim free. Wzmacnia to siłę perswazyjną - słowo wolny w znaczeniu 'dostępny', zostało powtórzone po polsku i po angielsku. Również aliteracja była tylko jedna Vivitek - vivid colours, vivid life.

Pod względem semantycznym przeanalizowane slogany tworzą niezwykle spójny, jednolity przekaz. Świat technologii jawi się jako środowisko przyjazne człowiekowi, np. at your side 'po twojej stronie', służące jego 
potrzebom, bezpieczne, np. we protect your digital worlds 'chronimy twoje cyfrowe światy', ergonomiczne, np. architecture for business. Designed to optimise the workspace 'architektura dla biznesu, zaprojektowane, by zoptymalizować przestrzeń pracy', kojarzące się z rozrywką, np. Enjoyment matters 'zadowolenie się liczy', sprzyjające utrzymywaniu więzi międzyludzkich, np. connecting people 'łączy ludzi', wreszcie doskonałe, np. the perfect simplicity 'doskonała prostota'. Technologia to styl życia, np. your lifestyle; My digital life 'moje cyfrowe życie', zadowolenie, np. simply enjoy, nastawienie na przyszłość, np. your vision, our future 'twoja wizja, nasza przyszłość', forward living 'życie naprzód/ku przyszłości', zmiany na lepsze, np. changes for the better.

O ile zapożyczenia właściwe nazywają techniczne szczegóły, służą przede wszystkim precyzji opisu i pełnią w tekście reklamowym głównie funkcję informacyjną, o tyle slogany spełniają funkcję perswazyjną, ich rolą jest budowanie pozytywnego obrazu technologii, odtechnicyzowanie świata komputerów. Można sądzić, iż w wypadku wprowadzania angielskich sloganów, również zakładana jest wysoka kompetencja odbiorcy - nie ma bowiem mniej lub bardziej ukrytych podpowiedzi dla czytelnika, angielskie wstawki funkcjonują samodzielnie, są niejako naturalnym składnikiem tekstu reklamowego.

W ostatnim $\mathrm{z}$ analizowanych czasopism, młodzieżowym magazynie „Dziewczyna”, co zaskakujące, odnotowano najmniejszą liczbę anglicyzmów. Tylko 15 zapożyczeń właściwych, w tym 3 cytaty - non stop, trendy $i$ women, 2 częściowo przyswojone - wideo i fotostory oraz 12 całkowitych o trojakiej pisowni:

a) angielskiej, np. look w znaczeniu wygląd: perfekcyjny look, owocowy fruit look; shopping 'zakupy'; gift 'prezent';

b) mieszanej: klip video, show biznes;

c) całkowicie spolszczonej: czip, gadiet, fon - spolszczenie angielskiego phone.

Większość z nich wpisuje się w polski system fleksyjny, np.: looku, fona, klipy, gifty, gadżety, oraz słowotwórczy, np. rozpikselowane okienko jako określenie monitora.

Sporo jest zapożyczeń sztucznych z prefiksem ekstra-zapisanym przez $x$, co można traktować jako graficzną stylizację na angielszczyznę. Większość $\mathrm{z}$ nich przybiera formę pisaną oddzielnie, np. extra objętość. Popularny jest 
także prefiks super- - superwyglad, supermodny. Hybrydy takie, mimo że zawierają przedrostki genetycznie łacińskie, tworzone są według angielskiego wzorca słowotwórczego (por. Markowski 2000: 1644).

Zapożyczenia strukturalne są sporadyczne, por. kalki słowotwórcze tworzone na wzór angielskich konstrukcji: trendlista, top lista, zapisywane łącznie bądź rozdzielnie; jedna kalka frazeologiczna - wyrażenie $n r 1$ na świecie $\mathrm{z}$ ang. 'number one over the world', oraz jedna znaczeniowa - gorqcy album $\mathrm{z}$ ang. hot w znaczeniu 'będący na czasie, modny'.

Wśród dłuższych wypowiedzi przeważają slogany właściwe oraz headline'y - slogany związane z jedną tylko kampanią reklamową, niebędące trwałym elementem marki. Najwięcej jest konstrukcji równoważnikowych, takich jak: for girls only 'tylko dla dziewcząt', Energy inside 'z energia w środku'. Rzadziej pojawiają się slogany zdaniowe: Be beautiful simply - po prostu bądź piękna.

Pod względem stosowanych zabiegów perswazyjnych sporo jest gier słownych, najczęściej jednak opartych na wkomponowaniu nazwy w slogan. Sa one łatwe do odczytania nawet dla odbiorcy, który nie zna angielskiego, np. It's a Big Star 'to wielka gwiazda' - gra słów z nazwą produktu, marką Big Star, oraz z warstwą wizualną - sloganowi towarzyszy zdjęcie piosenkarki Dody; It's always too late 'zawsze jest za późno' - w slogan wkomponowana została angielska nazwa marki reklamowanych zegarków Too Late. Tylko raz pojawia się slogan oparty na bardziej złożonej grze słów: hard as nails, wykorzystujący polisemię leksemu nail oznaczającego w języku angielskim zarówno paznokieć, jak i gwóźdź. Powstaje zatem skojarzenie paznokieć twardy jak gwóźdź, a więc mocny.

Konkludując, należy stwierdzić, iż różnice dotyczą przede wszystkim sposobów wprowadzania i funkcji anglicyzmów w tekstach reklamowych. W magazynie specjalistycznym służą one precyzyjnemu przekazywaniu treści, pełnią funkcję głównie informacyjną, często są konieczne, jako że nie posiadają jednoznacznych polskich odpowiedników lub też należą do terminologii komputerowej, używanej przez informatyków na całym świecie. Nie są wówczas tłumaczone ani wyjaśniane, funkcjonują niejako autonomicznie. Nadawcy reklam wprowadzają całe opisy produktów i hasła reklamowe w języku obcym, zakładając wysoką kompetencję odbiorcy.

W tygodniku „Wprost” trudniejsze techniczne terminy są objaśniane. Czytelnik, nawet jeśli nie zna dobrze języka angielskiego, otrzymuje w tek- 
ście podpowiedzi, w postaci gry tekstu polskiego z angielskim czy też ilustracji graficznej do anglicyzmu. Znaczenia słów może domyślić się na podstawie kontekstu.

W „Dziewczynie” dominują zapożyczenia sztuczne, liczy się zapis graficzny stylizowany na angielski. Anglicyzmy pełnią raczej rolę swoistego ozdobnika, nie wnoszą nowych treści, gdyż wiele z nich posiada polskie odpowiedniki o identycznym znaczeniu. Większość z nich przeniknęła do języka reklamy za pośrednictwem języka młodzieży, uzasadnione wydaje się zatem twierdzenie, iż pełnią one rolę przede wszystkim perswazyjną - dostosowują język reklamy do języka, jakim posługują się odbiorcy.

Pomimo różnic dają się wyodrębnić także cechy wspólne. Najbardziej widoczną z nich jest nieustabilizowana forma graficzna, niekonsekwentna pisownia poszczególnych zapożyczeń we wszystkich trzech czasopismach. Leksemy, takie jak dealer, video, surfować, online, przybierają zarówno spolszczone, jak i angielskie formy zapisu. Być może wynika to z faktu, iż obydwie formy są uznawane za poprawne.

Wspólną cechą są także proporcje występowania poszczególnych typów zapożyczeń: stosunkowo niewielka ilość kalk i zapożyczeń semantycznych oraz wyraźna dominacja zapożyczeń właściwych w dużym stopniu lub całkowicie przyswojonych. Angielskie dłuższe cytaty najczęściej przybierają formę sloganów, rzadziej zdań wplecionych w tekst czy kilkuzdaniowych wypowiedzi.

Analiza nawet tak niewielkiego wycinka bogatego zasobu reklamy prasowej, pozwala wykryć pewne tendencje. Anglicyzmy przede wszystkim pomagają opisać nową, szybko zmieniającą się rzeczywistość, nowe zjawiska, produkty czy technologie, ale jednocześnie stają się elementem zabiegów czysto perswazyjnych, służą kreowaniu reklamowego świata przedstawionego. Angielskie frazy, zwłaszcza w postaci sloganów, bywają źródłem gier słownych i słowno-graficznych, mają coraz większą autonomię w obrębie tekstu reklamowego, stanowią jego naturalny komponent. Obcość przestaje być obca, nawet jeśli nie do końca zrozumiała, to oswojona ilustracją, wskazówką w polskim tekście, czy łatwą do odczytania polsko-angielską grą słów. Nie sposób przewidzieć, jak w systemie języka polskiego potoczą się losy widgetów, rozpikselowanych okienek czy paroizolacji. Jedno jest natomiast pewne - wpływ języka angielskiego na język tekstów reklamowych jest wciąż znaczny. 


\section{Bibliografia}

Anisimowicz A., 2001, Spójnościowe aspekty zapożyczeń angielskich we współczesnej prasie polskiej, w: G. Habrajska (red.), Język w komunikacji, t. 3, Łódź: Wydawnictwo Wyższej Szkoły Humanistyczno-Ekonomicznej, s. 13-21.

ChŁopicki W., Świątek J., 2001, Wpływ języka angielskiego na współczesny język polskiej reklamy, w: G. Habrajska (red.), Język w komunikacji, t. 1, Łódź: Wydawnictwo Wyższej Szkoły Humanistyczno-Ekonomicznej, s. 319-326.

Dunas B. (red.), 2001, Stownik współczesnego języka polskiego, Warszawa: Przegląd Reader's Digest.

FisiaK J. (red.), 2003, Nowy stownik Fundacji Kościuszkowskiej angielsko-polski, New York: The Kosciuszko Foundation.

Kochan M., 2003, Slogany w reklamie i polityce, Warszawa: Trio.

Markowski A. (red.), 2000, Nowy stownik poprawnej polszczyzny PWN, Warszawa: Wydawnictwo Naukowe PWN.

OtwinowsKa-KaszTelanic A., 1998, Wpływ języka angielskiego na polszczyznę, Poradnik Językowy, z. 1, s. 57-65.

PhiliPs J. (red.), 1997, Oxford Wordpower. Stownik angielsko-polski, Oxford: Oxford University Press.

Polański E. (red.), 2007, Wielki słownik języka polskiego, Kraków: Krakowskie Wydawnictwo Naukowe.

Szaniawski J., 1997, Duży stownik informatyczny, Warszawa: Arskom.

\section{The expansion of Anglicisms in Polish press advertising}

( su m mary)

The aim of the article is to show the tendencies in the expansion of English loanwords in the language of Polish press advertisements. The analysed material has been drawn from three different types of press: weekly magazines, specialist press, and magazines for teenagers. This choice of sources allows to show a strict relation between form, amount and ways of incorporating Anglicisms, and the target reader. The analysis focuses on types of English loanwords used in examined advertisements, and their functions within the advertising texts. 